\title{
PUČKA GRADNJA KAO EVOLUCIJSKA SINTEZA IDEJNE, EMOTIVNE I MATERIJALNE KOMPOZICIJSKE KOMPONENTE
}

\author{
Helena Knifić Schaps \\ Arh projekt d.o.o. Zagreb \\ Oboj 68 \\ HR 10000 Zagreb \\ arhprojekt@inet.hr
}

UDK: 728.6(497.5 Podgorje)

39:72(497.5 Podgorje)

Izvorni znanstveni članak

Ur.: 2017-01-19

Podgorsko je pučko graditeljstvo nezaobilazna sastavnica prostornog $i$ duhovnog ustroja hrvatskog nacionalnog bića

Vjekovni život čovjeka u Podgorju, u podnožju Velebita, oduvijek je bio esencijalno vezan uz planinu, sa stalnim sezonskim selidbama i izlascima radi ispaše i vode.

Za pučku se gradnju Podgoraca, i onu uz more i onu u višim predjelima, može reći da predstavlja "arhitekturu koju je proizvela svrha", čvrsto utemeljenu u potrebi, krajoliku, klimi, funkciji i lokalnom materijalu.

S aspekta arhitektonske struke nedostatno je evidentirana i nije valorizirana, što radi marginalnosti teme, pomanjkanja interesa, veličine područja na kome se prostire i odselidbe stalnog stanovništva, a to i radi dijelom teškog i nepristupačnog terena. U novije doba cijelo područje potpada pod nekoliko razina zaštite prirode (od UNESCOve do nacionalne), gdje se za život autohtonog življa i njegova graditeljskog fonda teško nađe razumijevanja. Spoznaje i istraživanja intenziviraju se u posljednjih 20 -ak godina, konstatirajući uglavnom napuštenost i propadanje najvećeg dijela zaselaka, ambijenata i pojedinačnih građevina. Kuće, gospodarski objekti, poljoprivredne površine, crkvice i drugo - u ruševnom su stanju, tek su rijetka naselja nastanjena.

Rad daje uvid u rezultate terenskih istraživanja gradnje za stanovanje objavljenih u knjizi "Velebit arhitektonski, Pučka gradnja u dijelovima Sjevernog i Srednjeg Velebita", kao i razmišljanja o mogućnostima i pravcima prostornog razvoja te njihovoj utemeljenosti u važećim zakonima i prostorno-planskoj regulativi. Autorica propituje ulogu politike i stručne javnosti u održivom razvoju zaštićenih, a depopuliranih područja, opstanak i značaj autohtonog stanovništva u zaštiti prirode, te graditeljsku baštinu pučkog graditeljstva kao sastavnicu nacionalnog identiteta.

Ključne riječi: Pučka gradnja, valorizacija, nacionalni identitet, autohtona zajednica, prostorni razvoj 


\section{PODGORJE GEOGRAFSKI}

Podgorje, kraj pod gorom, stisnut morem i Velebitom, pržen suncem, šiban vjetrom, pljuskan valom....

Iako se Podgorjem smatra predio od Svetog Jurja do Starigrada Paklenice, odnosno od mora do nešto iznad Jadranske magistrale, geografsko se određenje ne poklapa s graditeljskim. Potonje predstavlja cijelo područje života autohtonog stanovništva u stalnom hodu za vodom, od mora, do viših i visokih područja Velebita. Sredinom 19. stoljeća u Gajevoj "Danici" nepoznati je autor pisao da se Podgorci u proljeće "uz planinu do sriedine penju", da ljeti "poberu marvu, te se pod varhove Velebita na tretje stanove presele, gdie obilnu pašu i barst za marvu, a led po gudurah za rastapanje i napajanje marve nalaze". Sve je uvjetovano klimom, jer kako navodi, u podnožju Velebita vlada "južnotalijanska klima", u srednjem dijelu klima "sieverne Niemačke ili Pruske", a po "varhu njegovom studen švedska ili sievero-ruska". A usto obrazlaže: "I to je uzrok da žitelji ovoga prediela nomadno žive tj. da se neprestano sele."1 Činjenica da je cijeli kraj bio naseljen, raseljavan i ponovo naseljavan od prapovijesti do nakon II. svjetskog rata, opće je poznata. Stoga ga je, u graditeljskom smislu, potrebno promatrati u svojevrsnom poprečnom presjeku područja kretanja i obitavanja autohtonog življa od mora do visokih područja kao: primorski dio do 300-500 m n. v. za život zimi, pode ili "srednju/sridnju planinu"2 500 - $1000 \mathrm{~m} \mathrm{n}$. v. za sezonsko te "gornju planinu" 3 i padeže iznad $1000 \mathrm{~m} \mathrm{n}$. v. za ljetno stanovanje.

\section{MATERIJALNI DOKAZI NASELJENOSTI}

Materijalni ostatci dokaza života u ovome kraju postoje i danas, u vremenu novovijeke raseljenosti, nedovoljno rekogniscirani i nikad valorizirani. Ne radi se samo o gradnji za potrebe stanovanja, već i o crkvicama, kapelicama, objektima tehničke kulture (šternama, gumnima, vrelima, ograđenim lokvama, trasama povijesnih cesta, branjevinama, ...), grobljima, grobovima, mirilima, a nadasve vrijednim ambijentima i vizurama kao bitnoj sastavnici kulturnog krajolika.

Koliko je graditeljsko naslijeđe nepoznato i malo istraženo dokazuje i činjenica da se čak ni ljudi poput arhitekta Aleksandra Freudenreicha, najtemeljitijeg "sakupljača" podataka i evidentiranja pučke gradnje uopće, nisu upuštali u to teško pristupačno područje. U knjizi "Narod gradi na

\footnotetext{
${ }^{1}$ Š. BALEN, 1985, 51.

2 S̆. BALEN, 1979, 40.

${ }^{3}$ H. KNIFIĆ SCHAPS, 2013, 32, 37.
} 
ogoljelom krasu"4 na karti br. 649 "Područje ogoljenog krasa u NR Hrvatskoj" nije označen, pa tako ni opisan, ni jedan lokalitet između Senja i Starigrada Paklenica. Ta činjenica kao da prethodi suvremenoj karakterizaciji hrvatskog obalnog područja, zastupljenoj u znanstveno-stručnim krugovima, gdje se on opisuje otprilike kao kraj koji "započinje blago položenom zapadnom obalom Istre, slijede ju rijetko naseljena zapadna i gusto naseljena istočna obala Kvarnera, crta strme obale oko Senja koja se nastavlja na otocima Rabu i Pagu, vraća se na niske Ravne Kotare, ...." ${ }^{5}$ itd. Kao da življa Podgorja niti je ikada bilo niti ga još uvijek ima.

Profesorica Ana Lemić, tijekom 20-godišnjeg samoinicijativnog i izvaninstitucionalnog istraživanja morske velebitske padine, fotografira i bilježi podatke o naseljima, planinskim stanovima i stanovništvu. Knjiga "Sela i stanovi na Velebitu - Svjedočanstva života od nastanka do nestanka" svojevrsna je zbirka zadataka za demografe, sociologe, arhitekte i prostorne planere, s popisom naselja cijelog područja istraživanja, i to: Primorske padine Sjevernog Velebita sa 116 naselja (uz more 15, podgorska zaravan do $300 \mathrm{~m} \mathrm{n}$. m. 42, podgorska zaravan do $600 \mathrm{~m} \mathrm{n.m.} \mathrm{27,} \mathrm{uzdužna} \mathrm{primorska} \mathrm{terasa} \mathrm{32),} \mathrm{Primorske}$ padine Srednjeg Velebita s 90 naselja (uz more 12, podgorska zaravan do 300 $\mathrm{m}$ n.m. 32, podgorska zaravan do $600 \mathrm{~m} \mathrm{n.m.} \mathrm{14,} \mathrm{uzdužna} \mathrm{primorska} \mathrm{terasa} 15$, visokoplaninska zona 17), Primorske padine Južnog Velebita sa 151 naseljem (uz more 29, podgorska zaravan 72, uzdužna primorska terasa 50) te Primorske padine Jugoistočnog Velebita s 45 naselja (uz cestu Sv. Rok - Obrovac 10, uz cestu Zadar - Gračac 35). Na primorskoj padini Velebita konstatira tako 402 naselja, stotinjak zaselaka, skupina kuća obiteljskih zajednica i pastirskih stanova, koji se mogu karakterizirati stalno, sezonski ili povremeno nastanjenima. Osim nekih naselja uz more i u podima, područje je depopulirano, a ostatci graditeljskog fundusa prepušteni propadanju.

\section{PROPISI AUSTRO-UGARSKE MONARHIJE KAO POTICAJ NASELJAVANJU}

O naseljavanju, gospodarenju drvom kao osnovnim blagom, te načinu i kvaliteti gradnje, brinula je ovdje još Austro-ugarska vlast donošenjem brojnih zakona, propisa i zabrana, s jasno izraženom namjerom: zadržati i/ili naseliti stanovništvo u granična područja radi obrane carstva od neprijatelja i što

\footnotetext{
${ }^{4}$ A. FREUDENREICH, 1962, 250.

${ }^{5}$ H. KNIFIĆ SCHAPS, 2013, 14.
} 
boljeg iskorištavanja šuma. Tako već dokumenti s kraja 18. stoljeća reguliraju gospodarenje šumama i drvetom kao temeljnim gospodarskim resursom koji omogućava život u Velebitu, uz poticanje drugih djelatnosti (lovstva, pčelarstva, morskog i slatkovodnog ribolova, uzgoj vinove loze, maslina, smokava, mendula itd.).

"Međutimski šumski red" (1746.) i "Instrukcije za šumarsko osoblje karlovačkog generalata" (1765.) donose odredbe o sječi šume, zabrani prekomjernog trošenja drva loženjem otvorenog ognjišta, pošumljavanju i slično. Uredba Marije Terezije "O lugov, dubrav i loz čuvanje i zadržavanje" (1769.) omogućava osnivanje prvih šumarija (u Krasnu i Oštarijama), a potom i pilana, dok posebna "Naredba" (1786.) propisuje štednju drvne građe i zabranjuje gradnju kuća drvom (osim krovne konstrukcije, talara i šimle).

U to se vrijeme osnivaju i rasadnici (u Grabarju 1876., pod Vratnikom 1878., kod Stinice, Lukova, Karlobaga i južnije), rezultat čega su još i danas vidljive šumske oaze na morskoj velebitskoj padini ograđene tzv. zabranom ili branjevinom. ${ }^{6}$

Podgorac i doseljenik u Podgorje svoju egzistenciju osigurava ljeti u Velebitu, a zimi uz more. U neprekidnom slijeđenju proizvodnih procesa povezanih s prirodom, njegov se život odvija sezonski, između morskih i gorskih stanova, ali i u cjelogodišnjoj obrani granica Carstva.

\section{ETNOGENEZA I PUČKA GRADNJA PODGORACA}

Arhitekt Andre Mohorovičić zaključuje da se "u pučkoj arhitekturi idejna i emotivna kompoziciona komponenta kristalizira spontano, dugotrajnom evolucijom, kao izraz osnovne funkcije arhitektonskog objekta" ${ }^{7}$. Pučko je graditeljstvo sastavnica svake etnogeneze, pa tako i one hrvatske i podgorske.

Proces stanovanja materijalizira se u Podgorju u prostornom volumenu stana, koji se najkraće može definirati kao "arhitektura koju je proizvela svrha"8, odnosno "arhitektura po sebi" ili "regionalna arhitektura"9 s karakteristikama gradnje koje nalazimo i u drugim područjima slične, ali nikad iste klimatske, idejne i materijalne potke. Nasuprot usporedivosti pojedinačnih elemenata, ambijentalne cjeline su neponovljive u svojoj jedinstvenosti. Dugotrajan evolucijski proces sazrijevanja prostorne definicije stana rezultira cjelinom

${ }^{6}$ H. KNIFIĆ SCHAPS, 2013, 27-28.

${ }^{7}$ A. MOHOROVIČIĆ, 1957, 10.

${ }^{8}$ A. FREUDENREICH, 1962, 165.

${ }^{9}$ B. MAGAŠ, 2011, 11. 


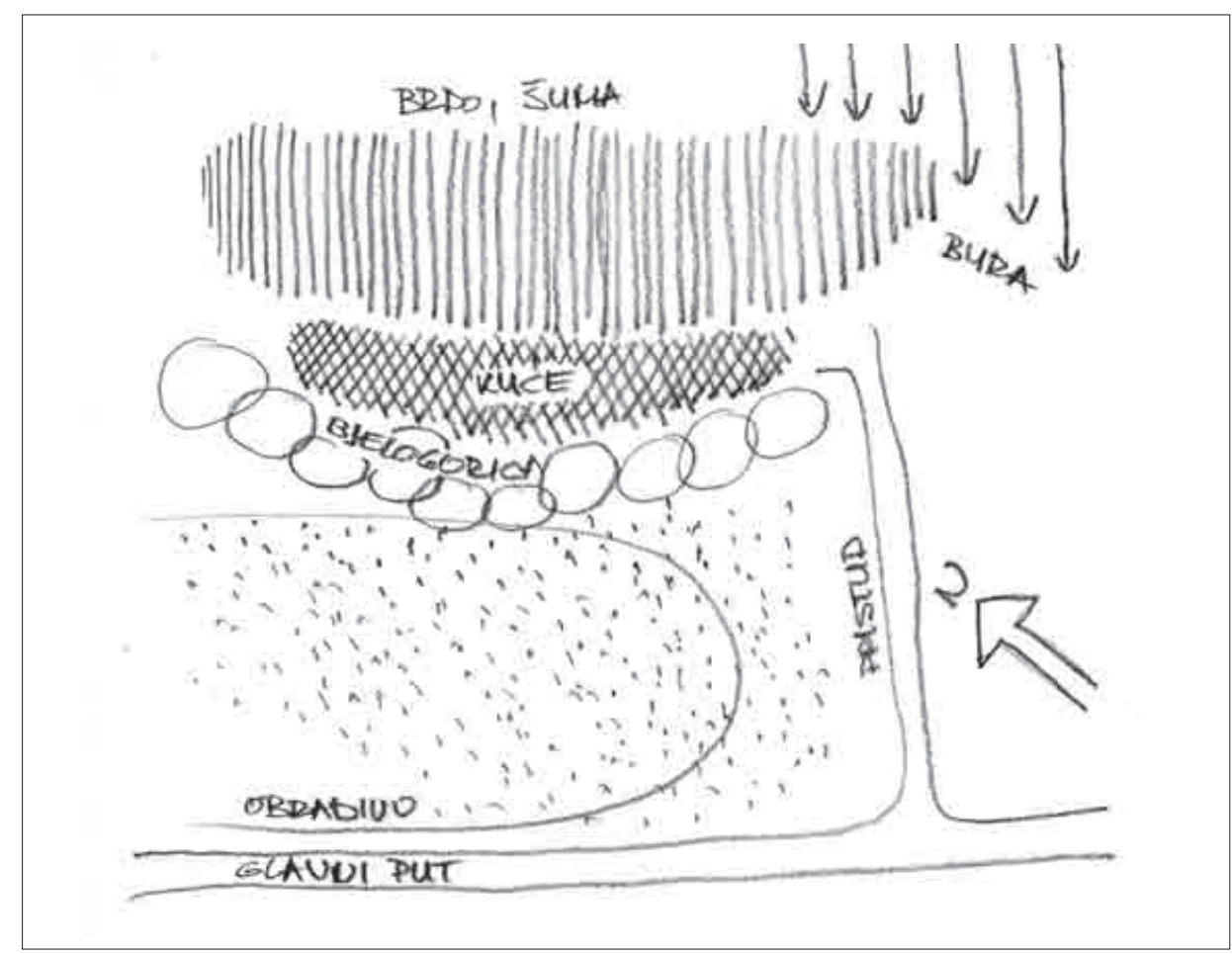

Sl. 1. Shema položaja naselja, H. Knifić Schaps, 2013, 47.

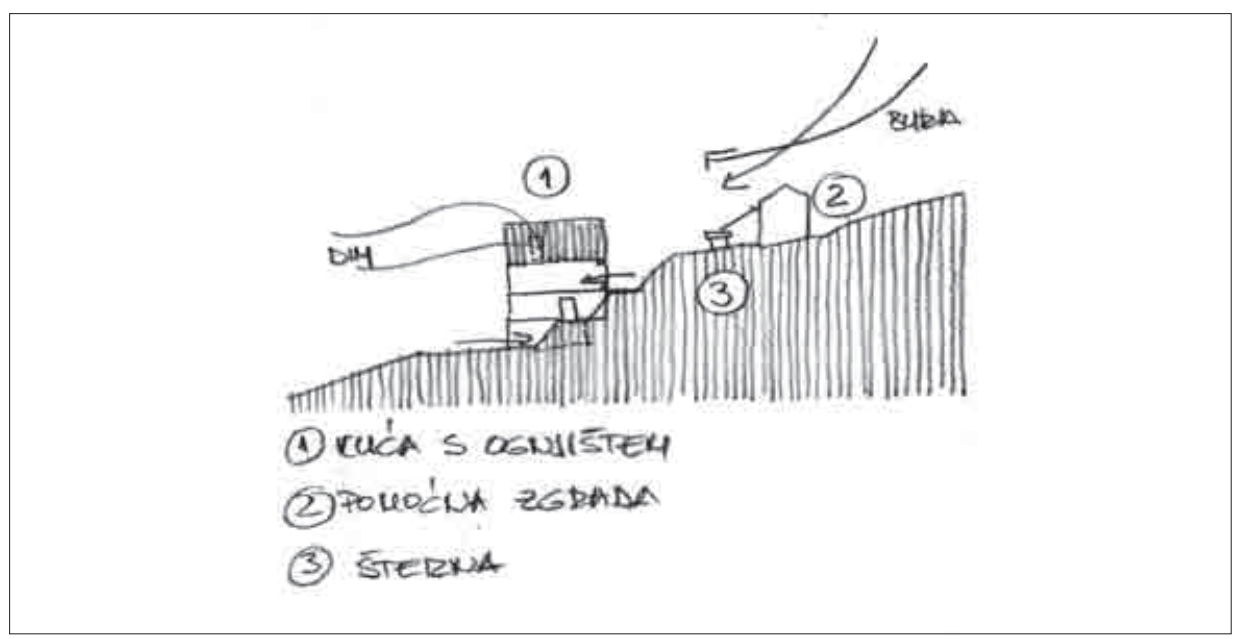

S1. 2. Shema položaja stana, H. Knifić Schaps, 2013, 48. 
kompozicijskih i konstruktivnih elemenata, uravnotežavajući mjerilo gradnje s tehničkim i estetskim svojstvima materijala.

U organizacijskom slijedu, stanovi za stalnije stanovanje u ljetnim mjesecima grade se do visine od 700 do $900 \mathrm{~m}$ n.v. i na udaljenosti 1-6 km, pa gotovo svaka kuća ima ljetni stan u blizini kojega uzgaja hranu za dnevne potrebe. Oni se postupno pretvaraju u stalna naselja, bogatiji živalj iz njih seli za vodom na veću visinu, u padeže, tako da "u tom prostoru ima oko 50 grupa ljetnih stanova, pored 81 stalno naseljenog zaseoka. Razlikovanje stalnog naselja od ljetnog stana ovdje nije jednostavno, o čemu govori i činjenica da su mnoga današnja stalna naselja ostala od nekadašnjih stanova. Osim toga, pitanje je treba li stanom, tj. privremenim boravištem, smatrati kuću u planini ili u Podgorju. ..."10.

Odabir lokacije za zasnivanje naselja i oblikovanje arhitektonskog volumena stana baziraju se na stoljetnoj empirijskoj spoznaji potreba i mogućnosti: od najpovoljnijih prirodnih uvjeta (orijentacije, zaklona, zaštite, blizine vode i obradive površine) pa do materijala za gradnju. Pučka je nastamba ekskluzivan prostor strogo odijeljen od vanjskog svijeta, za zadovoljavanje iskonske potrebe čovjeka za zaštitom, gotovo izolacijom od krajolika i svekolikih vanjskih utjecaja. Pučki graditelj nema potrebu za vizurom kao atrakcijom, već za ostvarivanjem kontrole nad vodom, blagom ili sigurnosti pristupa. Planinski je stan suhozidna građevina podignuta u "ugodnim dolinicama", u zaštiti od bure, uz komadić obradive površine za krumpir, zelje i ječam, uvijek u blizini vode. Znalo ih je tako biti okupljeno i desetak. Stan je nizak da se jedva može uspraviti, jedna prostorija od 4 do $10 \mathrm{~m}^{2}$ za boravak, spavanje i kuhanje na otvorenom ognjištu, s malo namještaja. Vrata su niska, nema prozora već samo videlica za odimljavanje, krov je pokriven šimlom. ${ }^{11}$ Nagib terena koristi se kao zaklon, tako da je većina stanova poluukopana.

\section{OBILJEŽJA PODGORSKE PUČKE GRADNJE}

Sve do izgradnje Jadranske magistrale 50 -ih godina 20. st., podgorska naselja nisu uzdužno povezana, nema čak ni ostataka rimskih puteva koji bi to omogućavali. Glavna su kretanja ona poprečna, prema otocima na jednu, i kontinentalnoj velebitskoj padini na drugu stranu. Prolaskom Magistrale ta se situacija mijenja utoliko što daje posrednu mogućnost povezivanja, jer je cesta trasirana predaleko i previsoko od naselja.

${ }^{10}$ Ž. POLJAK, 1969, 205.

${ }^{11}$ A. RUKAVINA, 1970, 99-123. 


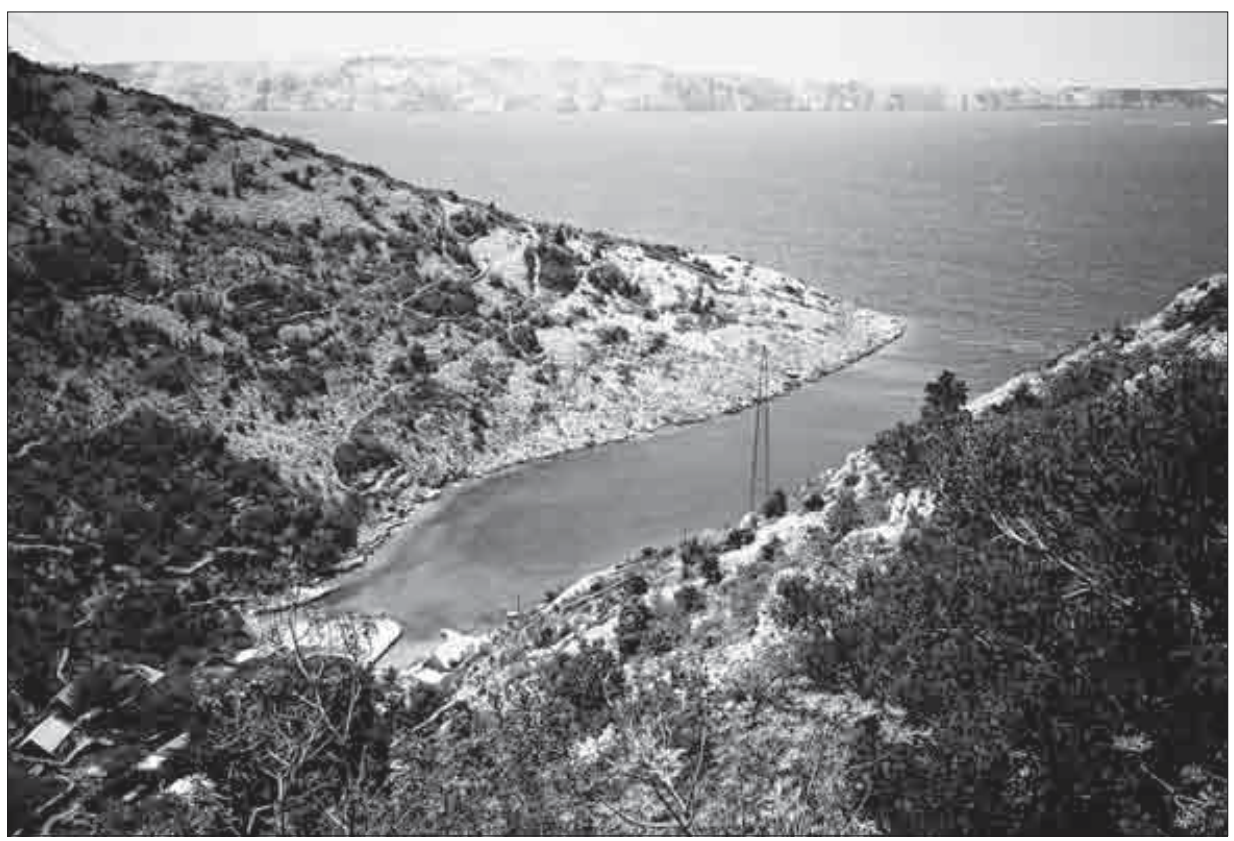

Sl. 3. Biluća, jedno od rijetkih naselja uz more okrenuto jugu, foto: H. Knifić Schaps, 2002.

Tipologija podgorske pučke gradnje za stanovanje u svojevrsnom se poprečnom presjeku razmatra na primjerima istraženim u Sjevernom i dijelu Srednjeg Velebita na lokacijama Biluće (primorje), Borovaca, Marame (sridnja planina), Turinskog Krča, Babrovače i Mirova (gornja planina). Razumijevanje geniusa loci problematiziraju primjeri 2015. rekonstruiranih stanova na Mirovu i Lubenovcu te spontane obnove Jovanović padeža. Pregled graditeljskih obilježja promatra se kroz odabir lokacije, način građenja te prilagodbe nastajale promjenom društvenih okolnosti i načina života.

Lokacija pogodna za zasnivanje naselja je blizina stalne vode; raskrižje putova iz smjerova uzdužnog i poprečnog kretanja; odvojak od glavne ceste/ puta (kontrola, sigurnost); podnožje brda (zaštita od vjetra); rub polja, obradivih površina ili pašnjaka; prisojni obronak. Naselja se zasnivaju na udaljenosti od 1 do $6 \mathrm{~km}$, prilagođeno pješačkoj komunikaciji.

Stan/kuća se gradi paralelno sa slojnicama, s bjelogoricom za zaštitu od sunca i pogleda.

Za građenje se koristi: materijal iz neposredne okolice (kamen, drvo); temeljenje na kamenu živcu (nema dubokog temeljenja); uglavnom prizemnica; 


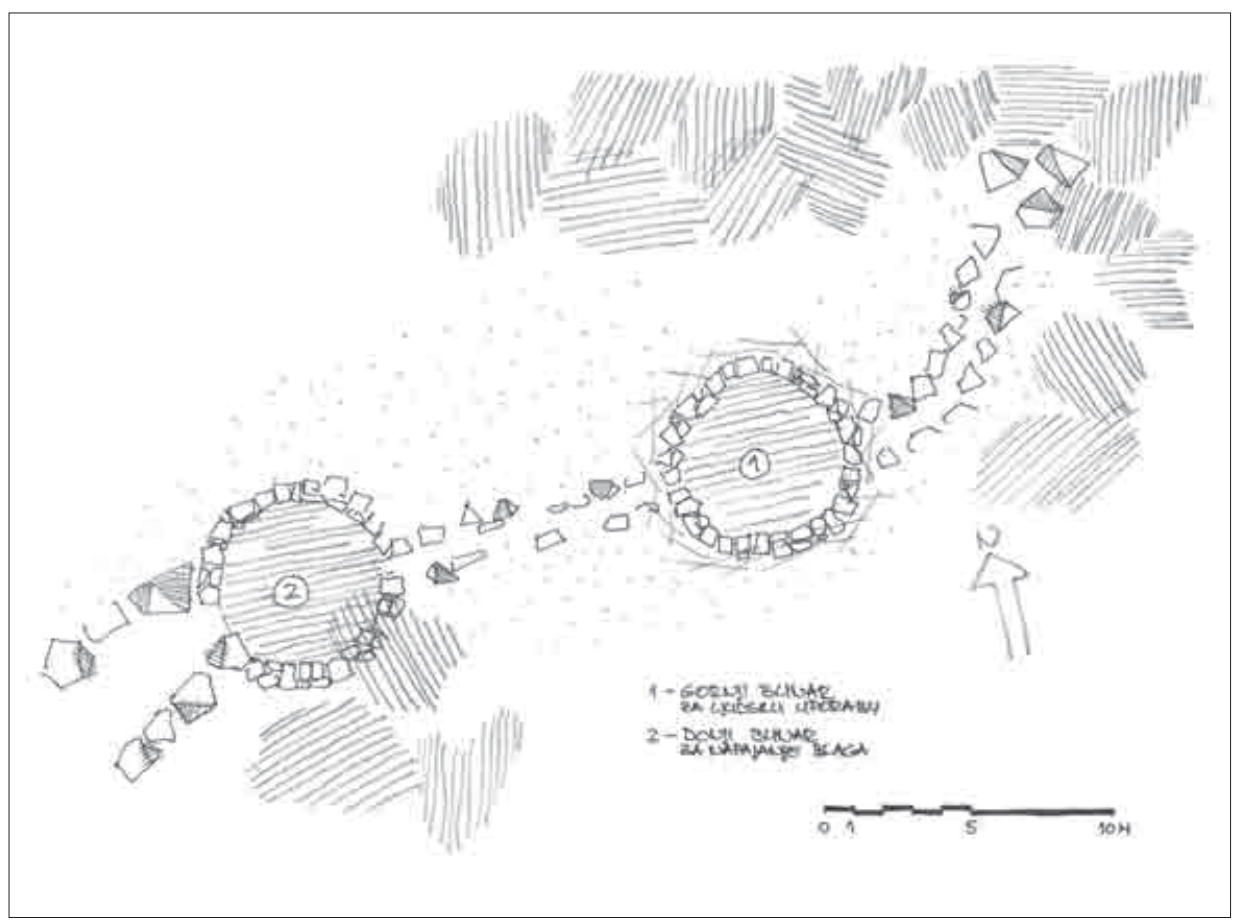

Sl. 4. Žive vodice, dva bunara (jedan za čovjeka, drugi za blago) na putu od mora u planinu, H. Knifić Schaps, 2013, 359.

kat (pod) uvjetovan nagibom terena; ulaz na svaki pod izravno s terena; štala pod stambenim dijelom; nema unutrašnje vertikalne veze; zid kameni, troslojni (vanjski slojevi iz većeg kamena, ispuna lomljenjakom uz dodatak sitnijeg materijala i zemlje); veličina kuće prilagođena osnovnim potrebama, mogućnosti grijanja i dimenziji drvne građe; prozori jednostruki, talari često od ostataka šimle (ograničava veličinu otvora na oko $1 \mathrm{~m}$ ); nema vanjske zaštite od sunca (kapci); ostakljenje jednostruko; ulazna vrata puna i uklađena, visine obično do nazidnice; međukatna konstrukcija drvena, pod daščan; krov dvostrešni, krovište roženično, građa jelova; pokrov šimlom, dvostruk. U stanu je otvoreno ognjište; prostor otvoren do krova (viši se podi koriste samo za dimljenje mesa); odimljavanje poklopcima u krovu (videlice/vidalice). Krov je nagiba oko $35^{\circ}$, bez snjegobrana. Voda za ljudsku upotrebu sakuplja se s čistog krova (štala), a samo se iznad ulaznih vrata postavlja segment žlijeba kao zaštita. Žljebovi su drveni na drvenim kukama ili kamenim konzolama (kasnije drveni na željeznim kukama). 


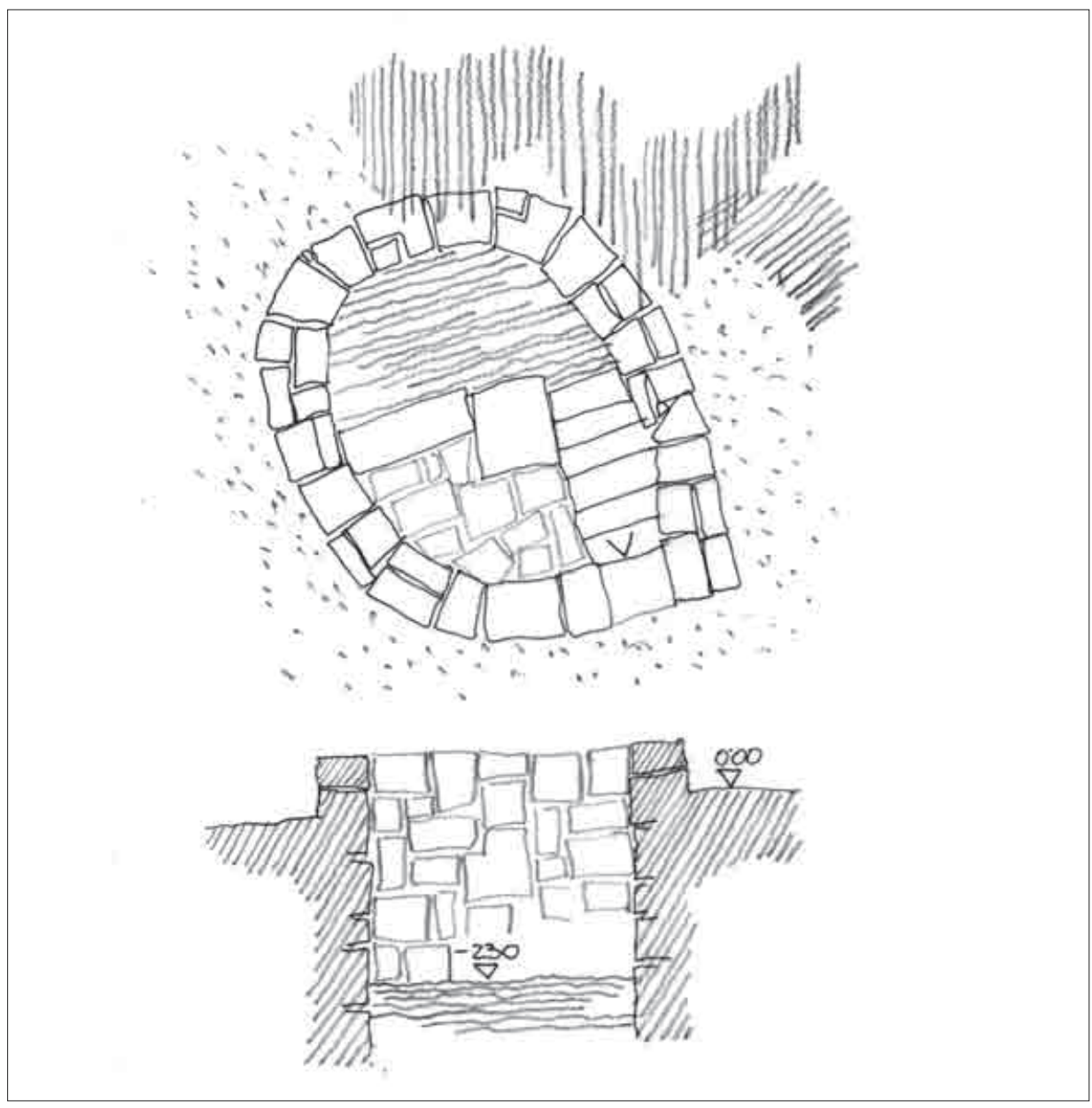

S1. 5. Bunar Gučinac kod Panosa, pouzdana opskrba vodom i za najvećih suša, H. Knifić Schaps, 2013, 353.

Promijenjeni način života i potrebe znatno utječu na način gradnje: kuće postaju veće, na jednoprostorne se dodaju još dvije do tri prostorije; štala se odvaja u posebnu zgradu; uvodi se dimnjak; napušta se otvoreno ognjište; pokrov azbest-cementnim pločama ("salonitkama") ili limom; voda se sakuplja sa svakog "čistog" krova, ne i s azbestnog; kuke za drvene žljebove kuju se od željeza; drvene žljebove zamjenjuje pocinčana limarija; krov nema snjegobrana; pred ulazom se dograđuje trijem; trijem se postupno zatvara i priključuje stambenom prostoru; prozori i vrata postaju veći, iz piljenih jelovih gredica i dasaka; prozori dvostruki, 
ustakljenje jednostruko; ulazna vrata uklađena i ustakljena; prostor prema krovištu se zatvara daščanim stropom; fasadni, unutarnji zidovi i strop se žbukaju; dijelovi pročelja i trjemova u gornjoj se planini oblažu drvenim daščicama.

Nakon Drugog svjetskog rata pristupne se ceste i središnja komunikacija unutar zaselka asfaltiraju, uvode se struja i telefon, te novi tip zgrade - garaža.

\section{PODGORSKA GRADITELJSKA BAŠTINA - UTOPIJA ILI RAZVOJNA PRILIKA}

"Kao što su za pravno postojanje države potrebne tri osnovne komponente: teritorij, pučanstvo i suverena vlast, tako je za determinaciju identiteta naroda potrebno navesti mnogo komponenata koje određuju narodno biće primarno formirano njegovom etnogenezom, rodovsko-biološkom povezanošću, kohezionom i asimilacijskom snagom, jezičnim idiomom, teritorijalnim okružjem, homogenim povijesnim tokovima, životnim navikama, običajnim konstantama, misaonim, kulturnim i umjetničkim profilom te mnogim drugim odrednicama."12

Kidanjem primarnog proizvodno-prehrambenog lanca Podgorca poprečnog kretanja i veza primorja s planinom - graditeljski kontinuitet nepovratno nestaje. Više se ne živi od prirode i s prirodom, a generiranje idejne i emotivne komponente građenja iz rentijerstva u turizmu daje posve neobične prostorne rezultate. Materijalna kompozicijska sastavnica postaje nekritična primjena gradiva i tehničkih mogućnosti iz tržišne ponude, sa slijeđenjem oblikovnih uzora mimo svake vlastitosti. Negiranje pučke gradnje svrstava ovaj naraštaj u "borbenu generaciju" koja je radi "boljitka, napretka i različitosti", nekritično se oduševljavajući "najnovijim napretkom", spremna prezrjeti baštinu iz koje je i sama ponikla ${ }^{13}$.

Pučka gradnja uživa za sada sudbinu uglavnom nevaloriziranog graditeljskog fundusa u nestajanju. Štiteći pravo na vlasništvo i imovinu, uz primjerenu edukaciju stanovništva, kreativnost i korištenje suvremenih tehnologija, planski se ne bi smjelo ukinuti više ni jedno postojeće naselje ili naseljska skupina, ma kako fragilan bio ekosustav u kojemu ono egzistira (primjer 10 naselja u Nacionalnom parku Plitvička jezera ${ }^{14}$ ).

${ }^{12}$ A. MOHOROVIČIĆ, 1989, 7.

${ }^{13}$ A. FREUDENREICH, 1962, 7.

14 Prostorni plan područja posebnih obilježja Nacionalnog parka "Plitvička jezera", Knjiga 1, 2014. http://plitvicka-jezera.hr/download/prostorni-planovi/pp-np-plitvicka-jezera2014/20140404_00-PPNPPJ_K1_OdlukaOdredbeNKP.pdf, 30 


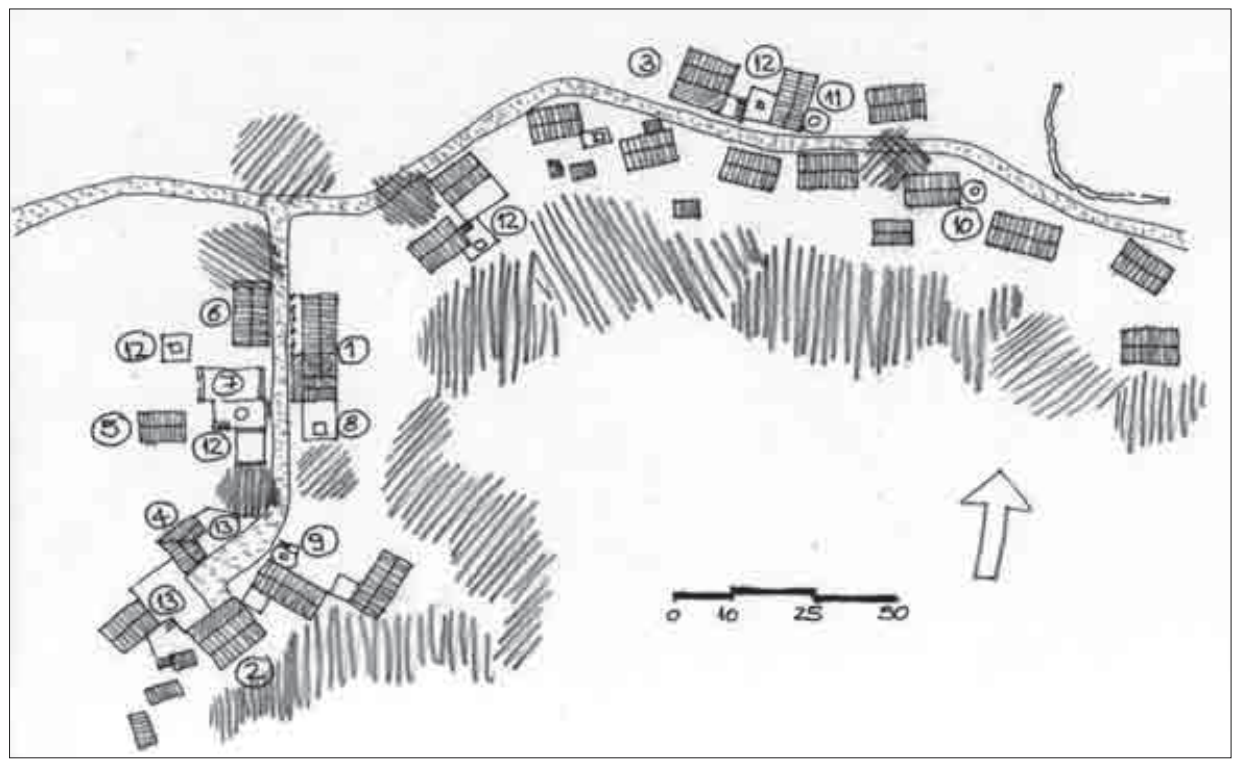

Sl. 6. Turinski Krč, Turine i Ažići, zaselak koji marom svojih zadnjih stanovnika uporno odolijeva vremenu, H. Knifić Schaps, 2013, 160.

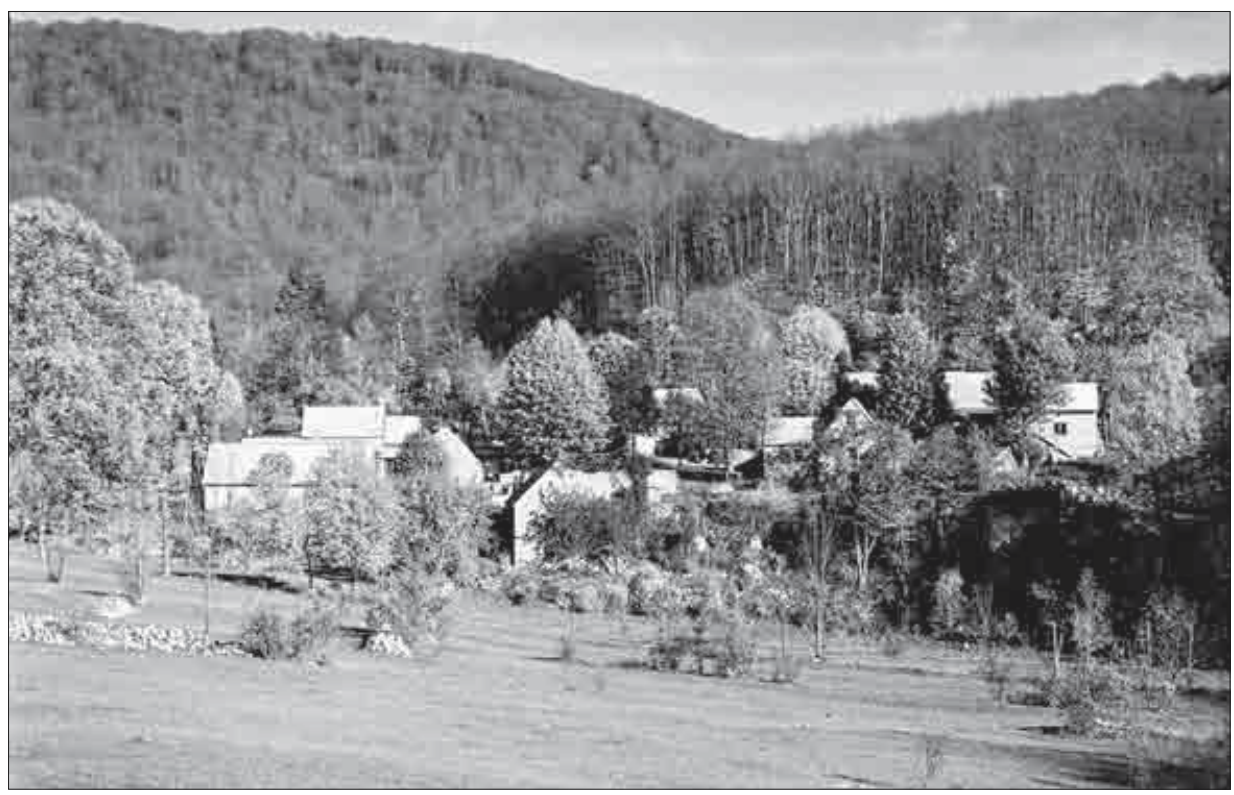

Sl. 7. Turinski Krč, Ažići, jedinstveni ambijent na morskoj padini Sjevernog Velebita, foto: H. Knifić Schaps, 2000. 


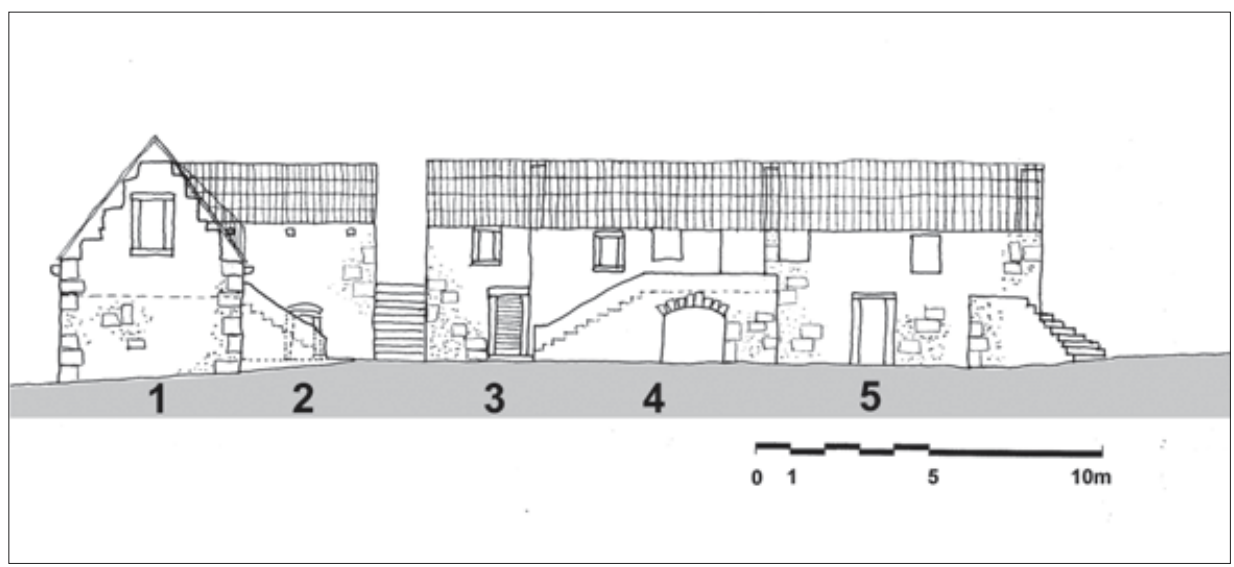

Sl. 8. Marama, kompleks od pet kuća Mandekića, Srednji Velebit, jugozapadno pročelje, moguće rekonstruirano stanje, H. Knifić Schaps, 2013, 322.

Antropofobnost upravo proporcionalna stupnju zaštite prirode kategorija je koja traži preispitivanje od prostora do prostora. Na negativne posljedice takve prakse upućuje nestajanje livada i njihova ekosustava u visokim područjima Velebita, kao posljedica nezaustavljivog širenja šume. Košnja tako velikog i dijelom nepristupačnog područja je nemoguća, pa kao jedini izlaz ostaje tradicionalno napasanje blaga. Ističe se to u svim planovima upravljanja sličnih područja, ali bez imenovanja izvršitelja. Upravo je zarastanje livada nominalni povod obnove stanova na Mirovu i Lubenovcu 2015. od Ministarstva zaštite okoliša i prirode. Model, međutim, može zaživjeti tek kad se obnova omogući i samim Podgorcima, vlasnicima propalih stanova (za sada to nije slučaj), naravno uz stručnu pomoć ${ }^{15}$.

Autohtona se zajednica u procesu zaštite prirode i obnove graditeljskog fonda potvrđuje kao prirodni saveznik i ravnopravan subjekt svugdje gdje postoji suživot. Vrijednost i ljepotu podgorske pučke gradnje čini upravo to logično i organsko definiranje životnog prostora, kao odraz prisnog odnosa prema prirodnim uvjetima i materijalu kojim se oblikuje arhitektonski korpus. Evolucijska je sinteza moguća samo ako proizlazi iz emotivne komponente kritične mase stanovništva s osjećajem pripadnosti i identifikacije s prostorom, pa samo naselja sa stalnim življem imaju veću ili manju autoregenerativnu sposobnost.

${ }^{15}$ Tako je Ministarstvo turizma izdalo stručne publikacije za obnovu, turističku valorizaciju i privođenje namjeni posavske kuće - korablje (2006), slavonske i baranjske kuće (2011) te kamene kuće dalmatinskog zaleđa (2015). 


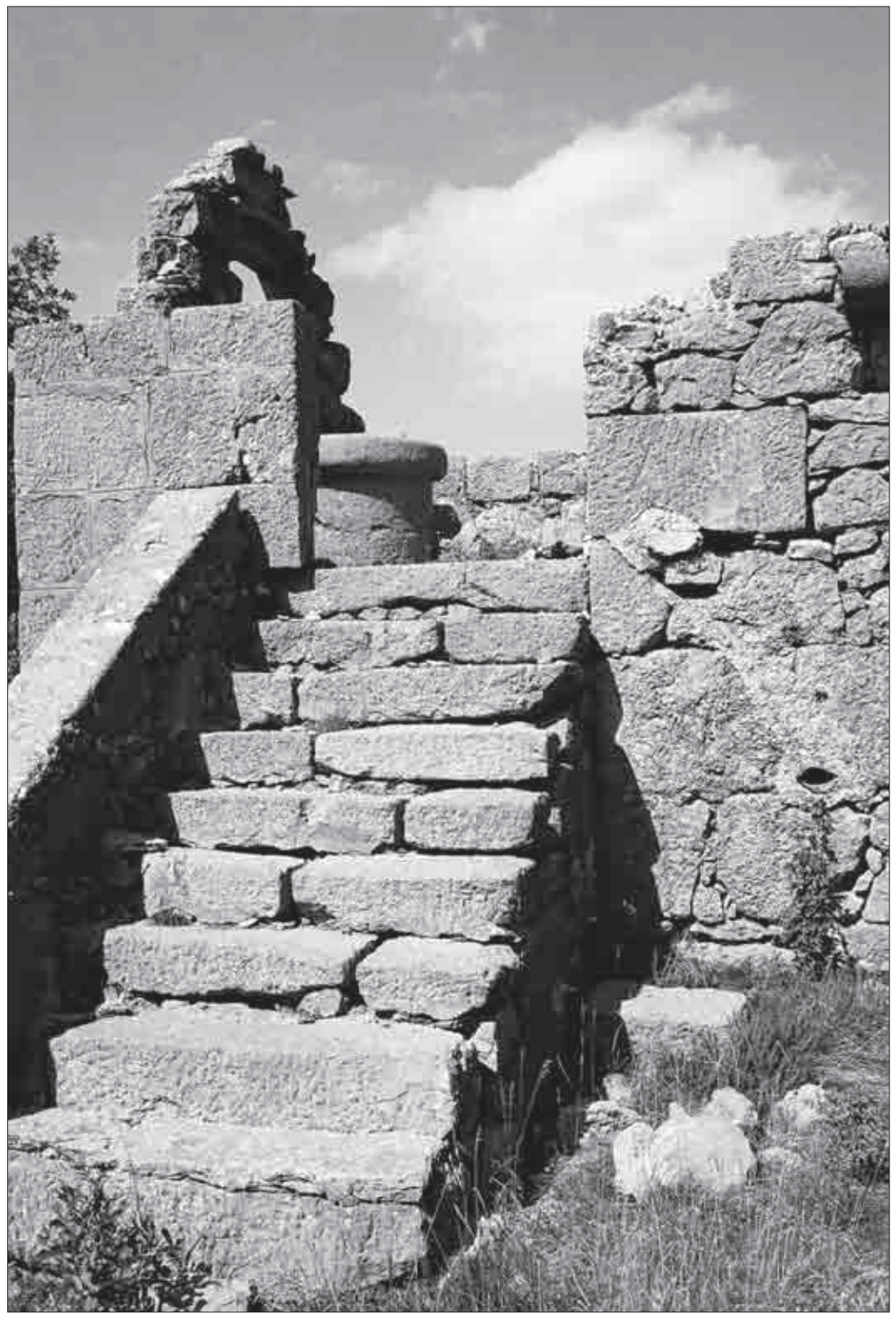

S1. 9. Marama, ostatci šterne u prvoj kući Mandekića, H. Knifić Schaps, 2013, 324. 


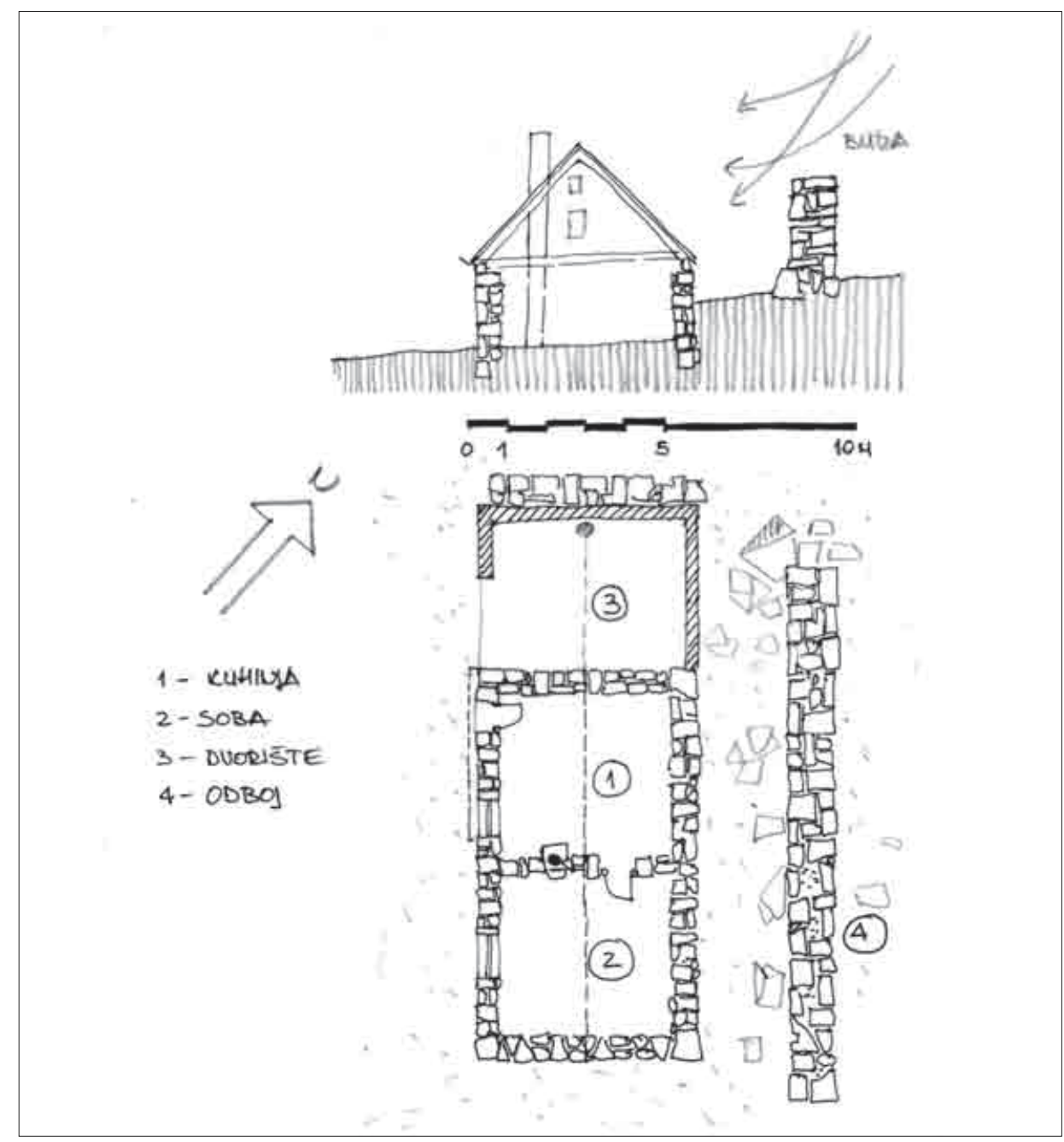

S1. 10. Borovci, kuća s odbojom, kamenim zidom za zaštitu od bure, arhitektonski snimak H. Knifić Schaps, 2013.

Svaka promjena namjene, kao u primjeru rekonstruiranih stanova na Mirovu i Lubenovcu, predstavlja izazov i pravu priliku za kreativnom reinterpretacijom arhitektonskog izraza. Puko kopiranje forme i gradnja faksimila otprilike je najgori način, često uvjetovan propisivanjem elemenata oblikovanja već u prostornoplanskoj dokumentaciji. Arhitekt Stjepan Planić upozorava da ni jedna knjiga o pučkom graditeljstvu "..... nema zadaću da dade pobornicima za 'nacionalno' 




S1. 11. Jovanović padež, foto: Svjetlana Lupret Obradović, 2002.

u arhitekturi neki album rekvizita i recepte za narodnjačko građenje, već ima isključivu svrhu da iscrpnom analizom upozori na bitnu organsku povezanost i svestranu uvjetovanost između gradiva, oblika, namjene, ekonomike, kraja, klime, načina života i društvenih odnosa u pojedinom vremenskom razdoblju."16 Za puko sakrivanje iza pseudostilskih obrazaca gradnje u ruralnim područjima arhitekt Boris Magaš je rekao da je "kupa kanalica alibi za zločin u arhitekturi"17.

Bolji i vjerojatno posljednji primjer (samoinicijativne) obnove naselja predstavlja Jovanović padež. Iako se više ne zovu stanovi nego vikendice, njih dvadesetak spontano ponavlja tradicijsku tlocrtnu i oblikovnu matricu, na temeljima stanova njihovih predaka. Zadržavanje izvorne funkcije i mjerila, te upotreba elemenata i detalja tradicijske gradnje, čine ovaj prostor povremenog stanovanja kompaktnom cjelinom. ${ }^{18}$ Zalažući se za izvrsnost i svevremensku

\footnotetext{
${ }^{16}$ S. PLANIĆ, u: A. FREUDENREICH, 1962, 3.

${ }^{17}$ Boris Magaš pri otvaranju izložbe u Muzeju arhitekture, Zagreb, lipanj 2006.

${ }^{18}$ H. KNIFIĆ SCHAPS, 2013, 214-216.
} 


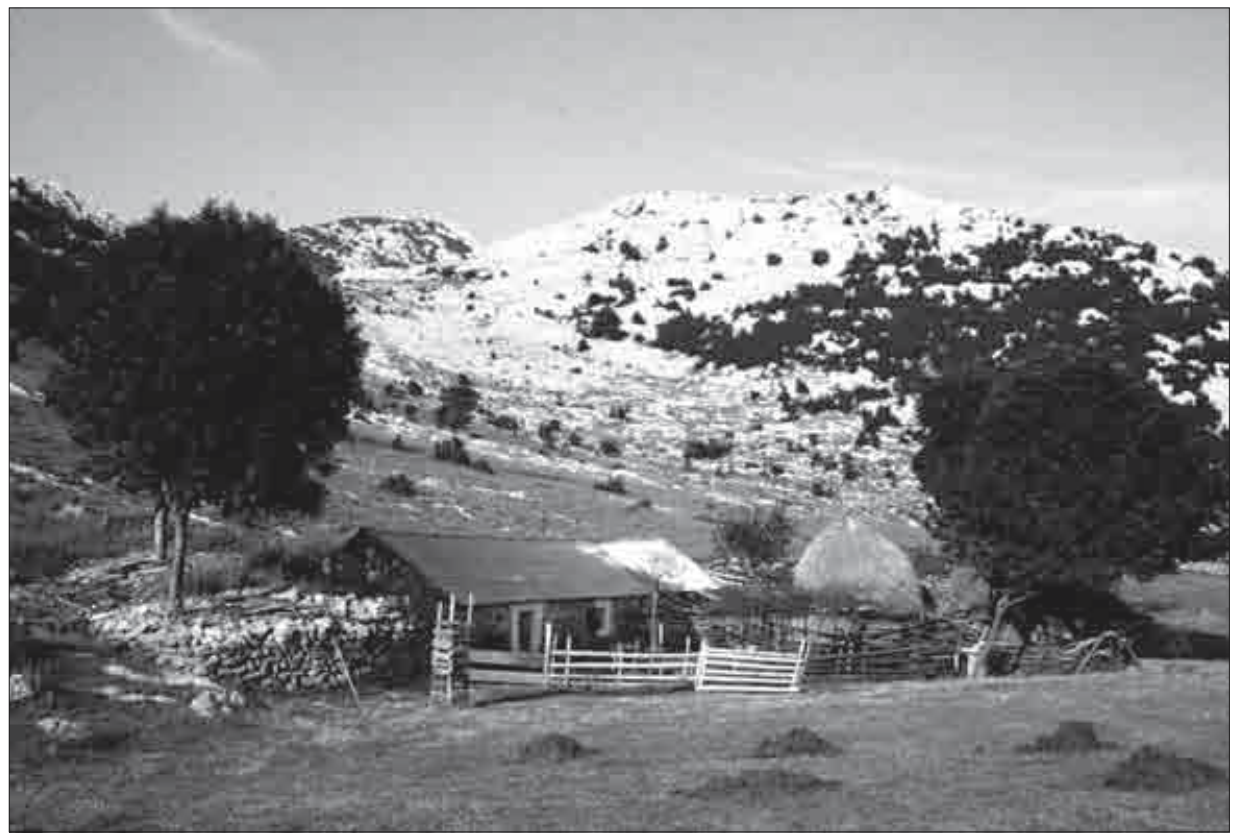

S1. 12. Velebitski pastirski stan 70-ih, foto: Srećko Božičević

komponentu nacionalnog identiteta kroz graditeljsku baštinu, arhitekt Boris Magaš ističe da sučeljavanje prošlog i suvremenog, svjetskog i regionalnog nije sukob, nego otvorena vrata novih mogućnosti. Da bi se taj put mogao ostvariti, moraju se definirati osnovni postulati koji određuju i pristup arhitekturi i njezinu kreativnu razinu i nužnost prosudbe vrsnoće. ${ }^{19}$

Odstupanja od tih principa karikaturalne su tvorevine, falsifikati, "resorti", tematski parkovi vulgarnog rentijerstva, nesposobni odoljeti stručnom vrjednovanju. Krajevi graditeljski tako nedvosmisleno introvertirani, kao što je to područje obitavanja Podgoraca, ne trpe neutemeljena podilaženja ni vremenu, ni platežnoj moći, ni tržišnim trendovima. Za razliku od drugih zaštićenih područja u Republici Hrvatskoj, nema ovdje bojazni od investicijskog vala krupnog kapitala i spekulativne trgovine zemljištem. Naprotiv, bez smislenih poticaja nema nažalost nade ni za značajnije naseljavanje. Ima li volje za dijalog o redefiniranju načina korištenja prostora? Političko opredjeljenje za socioekonomskom revitalizacijom traži suptilna znanstvena i stručna polazišta u

${ }^{19}$ B. MAGAŠ, 2011, 9-13. 


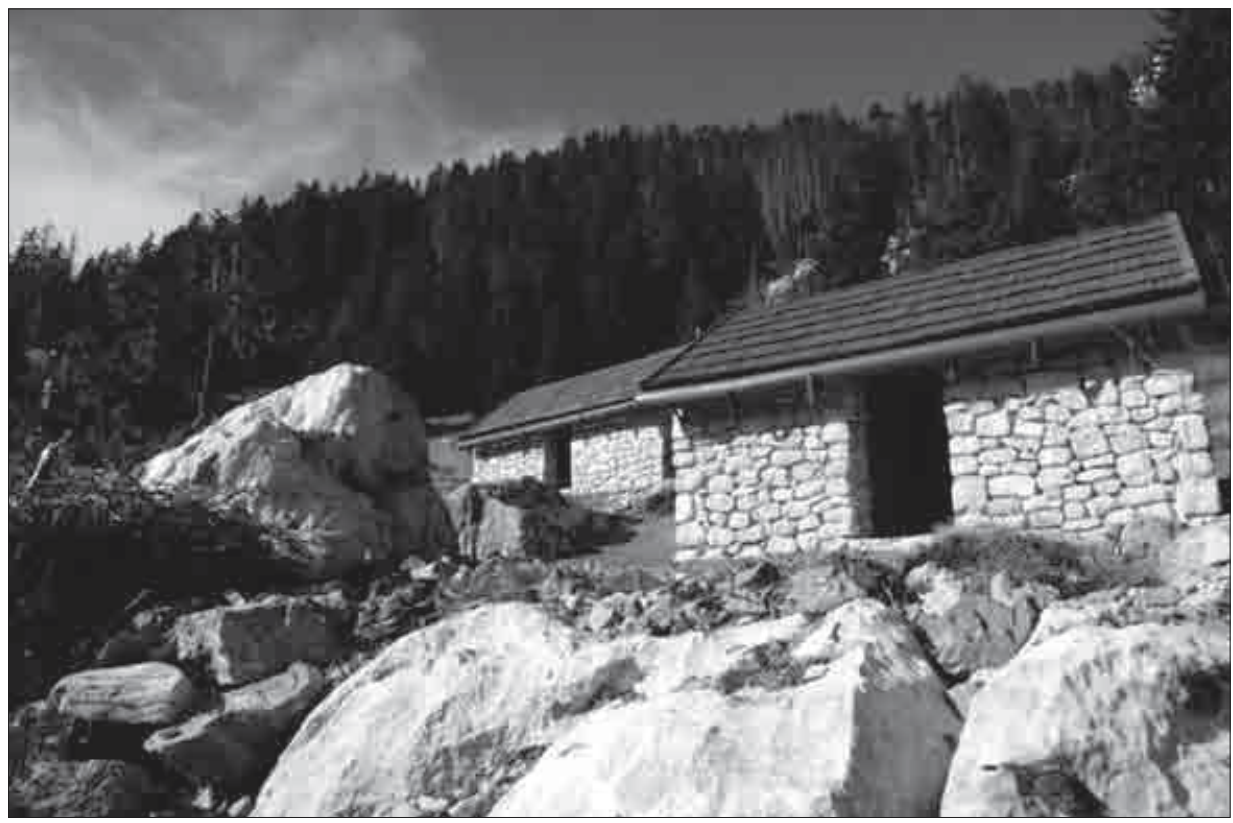

S1. 13. Obnovljeni stanovi na Lubenovcu, foto-arhiva Ministarstva zaštite okoliša i prirode, 2015.

rješavanju kompleksnih pitanja (dostupnost prometne, komunalne i društvene infrastrukture i drugo), mučnu i nezahvalnu borbu za afirmaciju kulturne i povijesne dimenzije graditeljskog kontinuiteta te pametno balansiranje sukobljenih interesa, prvenstveno na relaciji zaštita-održivi razvoj - ekonomska isplativost.

\section{REGULATORNI OKVIR ZA ODRŽIVI RAZVOJ, TEMELJ I PRETPOSTAVKA ZAŠTITE GRADITELJSKE BAŠTINE}

Za razumijevanje današnjeg stanja i razvojnih perspektiva, potreban je kraći uvid u relevantnu zakonsku regulativu koja se odnosi ne samo na brdsko-planinsko područje (u ovom slučaju priobalni pojas Podgorja kao životno nedjeljiv od viših i visokih predjela), već i na gravitacijsko područje regionalnih i mikrocentara (osobito Senja).

Velebit je, kao i svi ostali dijelovi Republike Hrvatske, pokriven zakonskom regulativom i dokumentacijom različitih prostorno-planskih razina, od one EU-a do lokalne. Osim citiranih dokumenata i drugih izvora, tu su još 
Prostorni plan Ličko-senjske županije (2015.), Prostorni plan Nacionalnog parka Sjeverni Velebit (2012), Plan upravljanja Nacionalnim parkom Sjeverni Velebit (2007.), Prostorni plan Zadarske županije (2006.), Prostorni plan područja posebnih obilježja Nacionalnog parka Paklenica (2001.) i drugi. Svi redom prepoznaju prirodne vrijednosti, vrijednosti povijesnih poluurbanih i ruralnih graditeljskih cjelina (ukoliko su rekognoscirane), ali i potencijale razvoja. U četiri osnovne skupine (Prepoznate vrijednosti, Ograničenja, Poticatelji razvoja, Prostorno-planske mjere), navodim samo neke od postavki, uz isticanje osnovnih pretpostavki svakog održivog razvoja - solidarnosti svih građana Republike Hrvatske te poticanje razvoja područja koja znatno zaostaju za nacionalnim prosjekom, ${ }^{20} \mathrm{u}$ cilju ekološki prihvatljivog i gospodarski samostalnog života stanovnika ${ }^{21}$.

Prepoznate vrijednosti prostora jesu:

- tradicijski oblici kulture; socijalna susjedska i rodbinska integracija i povezanost; ruralni prostor kao ekološki ugodno obitavalište; sustavno opremanje urbanom infrastrukturom i opremom; moguća laka i brza povezanost; velike pašnjačke površine; čist okoliš; potencijal za razvoj akvakulture i marikulture, vodarstva, ekološke i proizvodnje autohtonih proizvoda. ${ }^{22}$

Razvojna ograničenja ističu se kao:

- velika prostorna raspršenost, nepovoljni reljef i funkcionalno fizionomska heterogenost područja; ${ }^{23}$

- starenje stanovništva i iseljavanje mladih iz područja udaljenih od regionalnih središta koje za posljedice imaju smanjeni interes za izgradnju, komunalno opremanje i održavanje infrastrukture ${ }^{24}$.

Poticatelje razvoja predstavljaju:

- kreditiranje subjekata malog gospodarstva uz subvenciju kamatnih stopa; institucionalna potpora; odobravanje jamstava na kredite poduzetnika; ${ }^{25}$

${ }^{20}$ Zakon o regionalnom razvoju Republike Hrvatske, 2014., 2

${ }^{21}$ Prostorni plan područja Grada Senja, 2003. http://www.senj.hr/Prostorni_Plan/Tekst/ knjiga\%201\%20-\%20PPUG\%20Senj\%20-\%2003\%20PLAN.pdf

22 Županijska razvojna strategija Ličko-senjske županije 2011-2013. http://licko-senjska.hr/ images/stories/dokumenti/ZRS.pdf, 86-87

${ }^{23}$ Prostorni plan područja Grada Senja, 2003.: 65, 66, http://www.senj.hr/Prostorni_Plan/ Tekst/knjiga\%201\%20-\%20PPUG\%20Senj\%20-\%2003\%20PLAN.pdf

${ }^{24}$ Strategija razvoja Grada Senja 2015.-2020., Senj, 2015. http://www.senj.hr/wp-content/ uploads/2016/03/Grad_Senj-Strategija_-razvoja_GS_2015-2020.pdf, 52, 53

${ }^{25}$ Strategija razvoja Grada Senja 2015.-2020., Senj, 2015. http://www.senj.hr/wp-content/ uploads/2016/03/Grad_Senj-Strategija_-razvoja_GS_2015-2020.pdf 88-90 
- razvoj i unaprjeđenje informatičke i elektroničke komunikacijske infrastrukture; stvaranje preduvjeta za razvoj marikulture; ${ }^{26}$

- održivo gospodarenje otpadom; stvaranje preduvjeta za učinkovito korištenje sunčeve energije, energije vjetra, hidroenergije i energije iz biomase; ${ }^{27}$

- poticajne razvoja malog gospodarstva mjerama namijenjenim fizičkim osobama koje imaju prebivalište i boravište na brdsko-planinskom području (npr. uvećani osnovni osobni odbitak, pravo ubiranja šumskih plodova, zakup poljoprivrednog i šumskog zemljišta); ${ }^{28}$

- prednost ostvarivanja prava na zakup lovišta i ostvarivanja ribolovnog prava za fizičke i pravne osobe ${ }^{29}$.

Prostorno-planske mogućnosti pretpostavljaju ${ }^{30}$ :

- jednakomjerno vrjednovanje prirodnih i antropogenih, ljudskom rukom dosegnutih prostornih vrijednosti (očuvanje karakteristika lokacije naselja, vizura i kultiviranog krajolika kao ravnopravnog faktora u formiranju pejzažnih karakteristika);

- zabrana izgradnje novih objekata na atraktivnim lokacijama;

- očuvanje arhitektonskih karakteristika tradicijske arhitekture (rekonstrukcija zaštićenih najvrjednijih objekata, sanacija i adaptacija starih objekata, mogućnost prenamjene u skladu s izvornim obilježjima prostora $\mathrm{i}$ očuvanje tradicijskih funkcionalnih značajki, upotreba karakterističnih materijala: kamen, drvo, šindra, kupa kanalica);

- zaštita ruralne strukture;

- osiguranje kreativne slobode interpretacije nove arhitektonske forme uz suvremena funkcionalna rješenja;

- negiranje klišea mimikrije ili sterilne upotrebe pseudostilskih obrazaca;

- decentralizirani sustav naselja s urbanim identitetom i sačuvanom urbanom tradicijom života: okosnicu razvoja mreže društvene infrastrukture čine Senj (manje regionalno/razvojno središte) i Sveti Juraj (malo područno središte), slijede ih Jablanac, Lukovo, Klada, Starigrad i Prizna (manja lokalna središta).

${ }^{26}$ Strategija razvoja Grada Senja 2015.-2020., Senj, 2015. http://www.senj.hr/wp-content/ uploads/2016/03/Grad_Senj-Strategija_-razvoja_GS_2015-2020.pdf, 167

${ }^{27}$ Strategija razvoja Grada Senja 2015.-2020., Senj, 2015. http://www.senj.hr/wp-content/ uploads/2016/03/Grad_Senj-Strategija_-razvoja_GS_2015-2020.pdf, 181

${ }^{28}$ Strategija regionalnog razvoja Republike Hrvatske 2011.-2013. http://www.mrrfeu.hr/ UserDocsImages/STRATEGIJA_REGIONALNOG_RAZVOJA.pdf, 44

${ }^{29}$ Zakon o brdsko-planinskim područjima, 2014.

${ }^{30}$ Prostorni plan područja Grada Senja, 200.: 82, 83, 65, 66. http://www.senj.hr/Prostorni Plan/Tekst/knjiga\%201\%20-\%20PPUG\%20Senj\%20-\%2003\%20PLAN.pdf 
Demografski pokazatelji bilježe u razdoblju od 1991. do 2011. neznatan porast broja domaćinstava za Sveti Juraj (od 234 na 238), Klada (17 - 22), Starigrad (10 - 11), dok ostala mjesta bilježe gubitak: Senj (2104 - 1943), Jablanac (60 27), Stinica (56 - 35), Volarice (62 - 34), Lukovo (36 - 26), Prizna (39 - 28) itd.

Što se dakle regulatorne osnove tiče, nema zapreka ni čuvanju, ni održavanju, ni održivom razvoju Podgorja i Velebita. Međutim, dobra namjera ili "institucionalni optimizam" (I. Rogić ${ }^{31}$ ) u već četvrtstoljetnoj praksi hrvatske državnosti ne daje rezultata. Stanje i (ne)zainteresiranost pokazuje i evidencija publikacije "Nacionalni katalog Ruralni turizam Hrvatske"32, koja za primorsko i planinsko područje Velebita nema evidantiran ni jedan lokalitet ruralnog turizma ili poljoprivrednog gospodarstva u službi turizma.

Savez Podgorca s prirodom je razvrgnut, naselja, nastambe i ostali ljudskom rukom stvoreni objekti nepotrebni i napušteni.

\section{ZAKLJUČAK}

Ovaj je tekst nastao temeljem dugogodišnjeg (cjeloživotnog?) iskustva Velebita i Podgorja, te Senja kao subregionalnog centra. Učenje i znanje posljedica su osobnog interesa i kontakata s prostorom i ljudima. Upravo iskustveni pristup smatram nužnim i jedinim pravim kad se radi o graditeljskom fundusu specifičnog područja kakvo je Podgorje s Velebitom.

Sudbina mu je usko vezana na čovjeka kao stalnog/povremenog stanovnika, koji mora imati interes za naseljavanje i preuzimanje rizika poduzetništva, uz prije navedene poticaje i pomoć. Metodologija koju se kod istraživanja pučke gradnje ne smije preskakati je identifikacija/rekognisciranje - valorizacija regulacija.

Identifikacija je bitna (i hitna), bilo da se radi o vizurama, ambijentalnim vrijednostima i ambijentima, pojedinačnoj gradnji (stambene i pomoćne zgrade, crkvice, kapelice, grobovi, groblja, mirila), utilitarnim objektima (šterne, bunari, ograđene lokve, gumna, burobrani/odboji, suhozidi, branjevine), objektima tehničke kulture (povijesne ceste, vlake, miljokazi, raspela, druga obilježja) i slično. Rekognisciranje nije moguće isključivo kabinetski, istraživanjem prilično oskudne građe koja je uglavnom plod individualnih inicijativa. Podrazumijeva institucionalnu zainteresiranost te suradnju i sabiranje kapitalnih znanja živih

\footnotetext{
${ }^{31}$ I. ROGIĆ - A. MIŠETIĆ - R. ZIMMERMANN, 2006, 318-322.

${ }^{32}$ Hrvatska gospodarska komora, Nacionalni katalog Ruralni turizam Hrvatske, Zagreb, 2015.
} 
svjedoka, organiziranost i provedbu na velikom i teško dostupnom području, zahtjevnih topografskih i klimatskih karakteristika.

Stručna, neovisna i kompetentna valorizacija navedenih kategorija-vizura, ambijentalnih vrijednosti i objekata - prethodi izradi kriterija za postupanje u zaštićenim te gradnju u rubnim dijelovima. Raspolaganje vlasništvom, čak i u područjima stroge zaštite, neotuđivo je pravo koje zahtijeva kontrolirano postupanje prema utvrđenim kriterijima, sukladno pravnim normama.

Znanje, educiranost, kreativnost, tehnološke i tehničke mogućnosti 21. stoljeća jesu pomoć i alati za suživot, ali uz trajnu svijest o dominaciji, zajedničkom i istovremenom utjecaju zemljopisnih i klimatskih čimbenika, biljnog i životinjskog svijeta, zajedničke sudbine i zajedničke povijesti stanovništva. Sve to objedinjeno stvara etnička, jezična i svekolika kulturna obilježja naroda.

Za održivi i ravnomjeran razvoj cijelog državnog teritorija potreban je čovjek-stanovnik. Jedino povratak Podgoraca na svoju djedovinu stvara uvjete da pučka gradnja, neponovljiva, jedinstvena i neodvojiva od čitavog područja njihova života, opstane i postane hrvatska tradicijska graditeljska baština.

\section{Literatura}

Šime BALEN, Jablanac, (1179.-1979.), Povijesna skica prigodom 800. obljetnice, Zagreb, 1979.

Aleksandar FREUDENREICH, Narod gradi na ogoljelom krasu, Savezni institut za zaštitu spomenika kulture, Zagreb - Beograd, 1962.

http://dizbi.hazu.hr/?object=dl\&id=28279

http://dizbi.hazu.hr/?object=dl\&id=28280, pregled 11.8.2016.

http://dizbi.hazu.hr/?object=dl\&id=13444, pregled 11.8.2016.

Helena KNIFIĆ SCHAPS, Velebit arhitektonski, Pučka gradnja u dijelovima Sjevernog i Srednjeg Velebita, Zagreb, 2013.

Ana LEMIĆ, Sela i stanovi na Velebitu - Svjedočanstva života od nastanka do nestanka, Zagreb, 2013.

Boris MAGAŠ, Identitet hrvatskog prostora i vrsnoća građenja, Perspektive prostornog razvoja Republike Hrvatske, Zbornik radova, Hrvatska akademija znanosti i umjetnosti; Ministarstvo zaštite okoliša, prostornog uređenja i graditeljstva; Savjet prostornog uređenja Republike Hrvatske, Zagreb, 2011, 9-13.

Andre MOHOROVIČIĆ, O analizi pučke arhitekture, Bulletin Instituta za likovne umjetnosti Jugoslavenske akademije znanosti i umjetnosti, god. 5, 1, Zagreb, 1957, 8-13.

Andre MOHOROVIČIĆ, Narodni život i običaji kao etnička i humana kategorija, Zbornik za narodni život i običaje, knj. 51, Jugoslavenska akademija znanosti i umjetnosti, Zagreb, 1989, 7-12. 
Stjepan PLANIĆ, Riječ arhitekta, u: Aleksandar FREUDENREICH, Narod gradi na ogoljelom krasu, Savezni institut za zaštitu spomenika kulture, Zagreb - Beograd, 1962.

Željko POLJAK i suradnici, Velebit, Planinarski savez Hrvatske, Zagreb, 1969.

Ivan ROGIĆ - Anka MIŠETIĆ - Ratimir ZIMMERMANN, Kuća pokraj mora, Institut društvenih znanosti Ivo Pilar; Ministarstvo zaštite okoliša, prostornog uređenja i graditeljstva Republike Hrvatske, Zagreb, 2006.

Ante RUKAVINA, Privreda ličke i primorska strane Velebita, Senjski zbornik, 4, Senj, 1970, 99-123.

\section{PUBLIC CONSTRUCTION AS AN EVOLUTIONAL SYNTHESIS OF A CONCEPTUAL, EMOTIONAL AND MATERIAL COMPOSITIONAL COMPONENT}

Summary

Podgorje public construction is an indispensable component of the spatial and spiritual makeup of the Croatian national being

Man's age-old life in Podgorje, in the foothills of Velebit, has always been linked essentially to the mountain, with the constant seasonal migrations and visits for grazing and water.

It could be said that the public construction the people of Podgorje, both that along the sea and in the higher regions, represents "architecture created by purpose", firmly based on the need, landscape, climate, function and with local material.

From the aspect of the architectural profession it is insufficiently documented and valorised, which is due to the marginality of the theme, lack of interest, the size of the area over which it is spread and the movement of the permanent population, and this is also partly due to the harsh and inaccessible terrain. Recently the whole region has come under some level of nature protection (from UNESCO's to national), where for the life of the indigenous population and its architectural fund understanding is difficult to find. The insights and investigations have intensified over the last 20 or so years, concluding mainly on the abandonment and deterioration of most of the hamlets, the settings and individual structures. The houses, farm buildings, agricultural areas, chapels and alike, in a derelict condition, are just scarcely inhabited settlements.

The paper gives an insight into the results of the field investigations of the residential construction published in the book 'Velebit arhitektonski, Pučka gradnja u dijelovima Sjevernog i Srednjeg Velebita' ('Velebit architectural, public construction in parts of Northern and Central Velebit'), as well as considerations about the possibilities and directions of spatial development, and their foundations in applicable laws and spatial-planning regulations. The author questions the role of politics and the professional community in the sustainable development of protected, yet depopulated regions, the survival and importance of indigenous populations in the protection of nature, and the architectural heritage of public architecture as a component of the national identity.

Keywords: Public construction, valorisation, national identity, indigenous community, spatial development 